\title{
Differential Responses of Tobacco to the Citrus Variegated Chlorosis and Coffee Stem Atrophy Strains of Xylella fastidiosa
}

\author{
Silvio A. Lopes, ${ }^{1,2, \dagger}$ Laudecir L. Raiol-Júnior, ${ }^{1,2}$ Simone C. Z. Torres, ${ }^{3}$ Elaine C. Martins, ${ }^{2}$ Simone S. Prado, ${ }^{4}$ \\ and Luís O. S. Beriam ${ }^{5}$ \\ ${ }^{1}$ Universidade Estadual Paulista, Jaboticabal, São Paulo, Brazil \\ ${ }^{2}$ Fundo de Defesa da Citricultura, Araraquara, São Paulo, Brazil \\ ${ }^{3}$ Universidade de Ribeirão Preto, Ribeirão Preto, São Paulo, Brazil \\ ${ }^{4}$ Empresa Brasileira de Pesquisa Agropecuária, Jaguariuna, São Paulo, Brazil \\ 5 Instituto Biológico, Campinas, São Paulo, Brazil \\ Accepted for publication 18 November 2019.
}

\begin{abstract}
Xylella fastidiosa comprises a diverse group of xylem-limited, insecttransmitted bacterial pathogens. In Brazil, the citrus variegated chlorosis (CVC) and coffee stem atrophy (CSA) diseases are caused by $X$. fastidiosa subspecies pauca transmitted by common insect vectors. No simple protocol allowing strain discrimination exists, making epidemiological studies, which are important for devising control measures, difficult to undertake. Here, we show that both strains can easily be distinguished based on the pattern of leaf symptoms that they induce on pin prickinoculated tobacco seedlings, namely small orange lesions and large necrotic lesions induced by the CVC and CSA strains, respectively. These differential responses allowed us to investigate whether mixed strain infections would occur in citrus or coffee trees in the field. Seedlings were
\end{abstract}

ABSTRACT individually inoculated with $X$. fastidiosa colonies recovered from citrus or coffee plants from various locations at three different times. No mixed infections were detected. In two experiments, the citrus and coffee strains infected only their original hosts as well as tobacco. The usefulness of this tobacco bioassay as a tool to study $X$. fastidiosa spread was demonstrated. It provided evidence that, over the years, the CVC and CSA pathogens have remained limited to their original hosts, despite crop proximity and the presence of sharpshooter vectors that favor transmission of the bacteria to and between both host species.

Keywords: bacteriology, disease management, epidemiology, etiology, inoculum sources, population biology
Xylella fastidiosa comprises a group of xylem-limited and insecttransmitted Gamma proteobacteria, causal agents of diseases in several economically important crops around the world. The species was described in 1987 (Wells et al. 1987) and later divided in five subspecies, with the subsp. multiplex affecting oak, American elm, sweetgum, and peach; the subsp. pauca affecting citrus, coffee, and olive trees; the subsp. sandyi affecting oleander; the subsp. fastidiosa affecting grape; and the subsp. morus affecting mulberry (Nunney et al. 2014; Schaad et al. 2004). Although much is known on genetic similarities among this diverse group of organisms, little is known on their host specificities. Knowing the host range is important for devising disease control measures. This can help determine how much an infected crop would serve as a source of inoculum to a neighboring crop.

In Brazil, X. fastidiosa subsp. pauca causes citrus variegated chlorosis (CVC) (Chang et al. 1993; Garnier et al. 1993; Rossetti et al. 1990), coffee stem atrophy (CSA), or coffee leaf scorch (de Lima et al. 1998; Paradela Filho et al. 1997). In 2016, the pathogen was also detected in olive trees (Coletta-Filho et al. 2016). In coffee and olive trees, no clear estimates of losses are available. However, in citrus, mainly because of a decrease in fruit size and the

†Corresponding author: S. A. Lopes; silvio.lopes@fundecitrus.com.br

Funding: This work was partially funded by Fundação de Amparo à Pesquisa do Estado de São Paulo grants 1999/04343-0 and 1999/04345-3 (to S. A. Lopes).

*The $\boldsymbol{e}$-Xtra logo stands for "electronic extra" and indicates that one supplementary table is published online.

The author(s) declare no conflict of interest.

(C) 2020 The American Phytopathological Society productive life span of the diseased trees (Ayres 2000), X. fastidiosa caused an estimated U.S. $\$ 100$ to 120 million a year in the State of São Paulo (SPS) and the Triângulo Mineiro region of Minas Gerais State alone (Bové and Ayres 2007; Lopes et al. 2004), where the incidence of diseased trees remained $>40 \%$ from 2003 to 2009 . Most probably as a result of a significant decrease in inoculum sources and vector populations resulting from a massive removal of abandoned groves and more frequent applications of insecticides (measures adopted in attempts to control huanglongbing), the incidence of CVC dropped to <2\% by 2018 (Fundecitrus 2018). However, despite this overall sharp decrease in incidence, CVC still remains a threat, especially in farms where the disease and vectors have not been controlled properly.

Particularly for citrus and coffee, there is still a concern about whether one host has been serving as the source of inoculum for the other, especially in farms where both citrus and coffee orchards are grown near to each other, a situation common in northern SPS and in Minas Gerais and Paraná States. Conditions for pathogen spread exist because the CVC and CSA strains are transmitted by same sharpshooter species (Hemiptera: Cicadellidae), and the insects occur in large populations in both crops (Marucci et al. 2008). Evidence for nonspecificity of the CVC pathogen has been presented. Through artificial inoculations with the use of pure cultures, it induced leaf scorch on potted coffee plants 6 months postinoculation ( $\mathrm{Li}$ et al. 2001). In another work, coffee plants also were infected by the CVC pathogen but only with the use of a inoculum suspension with bacterium titer 10-fold higher than that needed to obtain a similar rate of infection in citrus (Prado et al. 2008). Also, the infection was transient in coffee, and the CSA pathogen did not infect citrus.

In 2000, we showed that tobacco was a host even more susceptible to the CVC pathogen than citrus and suggested that it could be used as a model plant for studies of host-pathogen 
interactions (Lopes et al. 2000). In tobacco, the CVC bacterium reached higher titers and induced small dark orange lesions on the leaf blade (Alves et al. 2003; Lopes et al. 2000) starting 2 months after inoculation. This incubation period was 1 to 4 months less than that in citrus. In 2001, we showed that tobacco is also susceptible to the CSA pathogen (Lopes 2001), with the infected plants exhibiting a pattern of leaf lesions distinct from that induced by the CVC pathogen, opening an opportunity to use tobacco to investigate mixed infections in field trees. The objectives of this work were to further characterize the responses of tobacco to the CVC and CSA strains and to test its suitability to investigate whether the CVC and CSA bacteria move between citrus and coffee crops in the field, information that could help growers to improve disease control. The study was carried out during three time periods in several geographic regions of Brazil.

\section{MATERIALS AND METHODS}

Pathogenicity tests. Initial pathogenicity tests were undertaken in 2001 and 2002, and repeated in 2014 and 2019 involving only tobacco or tobacco and the citrus and coffee cultivars Pera and Catuaí Amarelo, respectively (Tables 1 and 2). Inoculations were carried out through injections in the stems of 60-day-old seedlings (citrus or coffee) or pin prick (tobacco) of 50- $\mu$ l phosphate-buffered saline (PBS) cell suspension of $X$. fastidiosa as described (Lopes et al. 2000, 2005). The inoculum was prepared from 20-day-old liquid periwinkle wilt (PW) cultures (Davis et al. 1981). Control plants were treated with PBS alone.

In 2002, the inoculum contained $1.1 \times 10^{9} \mathrm{CFU} / \mathrm{ml}$ for the $\mathrm{CVC}$ pathogen and $2.7 \times 10^{8} \mathrm{CFU} / \mathrm{ml}$ for the CSA pathogen; these were estimated based on serial dilution plating on solid PW medium. The CVC pathogen was the 9a5c strain, the same used during the genome sequencing project (Simpson et al. 2000), which was originally obtained in 1992 from an affected sweet orange tree (Citrus sinensis [L.] Osbeck 'Valencia') from Macaubal municipality in northern SPS (Fig. 1). It was recovered in culture from an infected young citrus tree maintained in a greenhouse at Fundecitrus. The CSA pathogen was the CaSC strain, which was isolated in 2002 on PW medium from an infected coffee tree (Coffea arabica L. 'Catuaí Amarelo') growing in a Santa Cecília farm located in Santa Rita do Passa Quatro municipality in eastern SPS (Fig. 1).

In 2014 and 2019, the inoculum consisted of unknown amounts of cells in liquid PW medium cultures initiated with isolated colonies recovered on agar plates from field trees from distinct locations. Forty isolates each from citrus and coffee trees that had induced symptoms in tobacco (see below) were used in 2014. One isolate from a citrus tree from Tabatinga and one isolate from a coffee tree

TABLE 1. Isolation frequency and population density of Xylella fastidiosa in leaves of artificially inoculated tobacco, citrus, and coffee seedlings

\begin{tabular}{|c|c|c|c|c|c|c|}
\hline \multirow[b]{2}{*}{ Host, species, and variety ${ }^{\mathrm{v}}$} & \multicolumn{3}{|c|}{ CVC strain $(9 a 5 c)^{w}$} & \multicolumn{3}{|c|}{ CSA strain $(\mathrm{CaSC})^{\mathrm{w}}$} \\
\hline & $\begin{array}{l}\text { Isolation } \\
\text { frequency }\end{array}$ & Percentage & $\begin{array}{c}\log _{10} \mathrm{CFU} / \mathrm{g} \\
\text { leaf tissue }\end{array}$ & $\begin{array}{l}\text { Isolation } \\
\text { frequency }\end{array}$ & Percentage & $\begin{array}{c}\log _{10} \mathrm{CFU} / \mathrm{g} \\
\text { leaf tissue }\end{array}$ \\
\hline Nicotiana tabacum 'RP1' & $8 / 8$ & 100 & $8.29 \pm 0.11 \mathrm{a}$ & $4 / 8$ & 50.0 & $7.49 \pm 0.28 \mathrm{a}$ \\
\hline Nicotiana tabacum 'Petit Havana' & $7 / 7(1)^{\mathrm{y}}$ & 100 & $8.27 \pm 0.12 \mathrm{ab}$ & $6 / 8$ & 75.0 & $7.55 \pm 0.31 \mathrm{a}$ \\
\hline Nicotiana clevelandii & 7/7 (1) & 100 & $7.60 \pm 0.26 \mathrm{abc}$ & $5 / 8$ & 62.5 & $7.33 \pm 0.37 \mathrm{a}$ \\
\hline Nicotiana tabacum 'TNN' & $7 / 7(1)$ & 100 & $7.60 \pm 0.07 \mathrm{bc}$ & $3 / 8$ & 37.5 & $7.70 \pm 0.42 \mathrm{a}$ \\
\hline \multicolumn{7}{|l|}{ Citrus } \\
\hline Citrus sinensis 'Pera' & $8 / 15$ & 53.3 & $6.37 \pm 0.56 \mathrm{c}$ & $0 / 15$ & 0 & n.d. ${ }^{z}$ \\
\hline \multicolumn{7}{|l|}{ Coffee } \\
\hline Coffea arabica 'Catuaí Amarelo' & $0 / 15$ & 0 & n.d. ${ }^{z}$ & $4 / 15$ & 26.6 & $3.93 \pm 0.57 \mathrm{~b}$ \\
\hline Totals & $47 / 73$ & 64.4 & $7.53 \pm 0.14$ & $31 / 73$ & 42.5 & $6.93 \pm 0.24$ \\
\hline
\end{tabular}

$\mathrm{v}$ The three groups of plants were inoculated at the stem through pinprick or stem injections of the inoculum and assessed 4 (tobacco) or 6 months (citrus and coffee) later. Means with the same letter are not significantly different from each other (Tukey, $P>0.05$ ).

${ }^{w}$ The inoculum consisted of a phosphate-buffered saline suspension prepared from pure cultures grown in periwinkle wilt medium. CSA, coffee stem atrophy; CVC, citrus variegated chlorosis.

x Average and standard error based on estimated number of $X$. fastidiosa colonies grown on buffered charcoal yeast extract agar medium 30 days after plating.

y Number of contaminated samples.

${ }^{\mathrm{z}}$ n.d., not detected.

TABLE 2. Tobacco, citrus, and coffee responses to infections by the citrus variegated chlorosis (CVC) or the coffee stem atrophy (CSA) isolates of Xylella fastidiosa recovered from infected trees in Sao Paulo state, Brazil

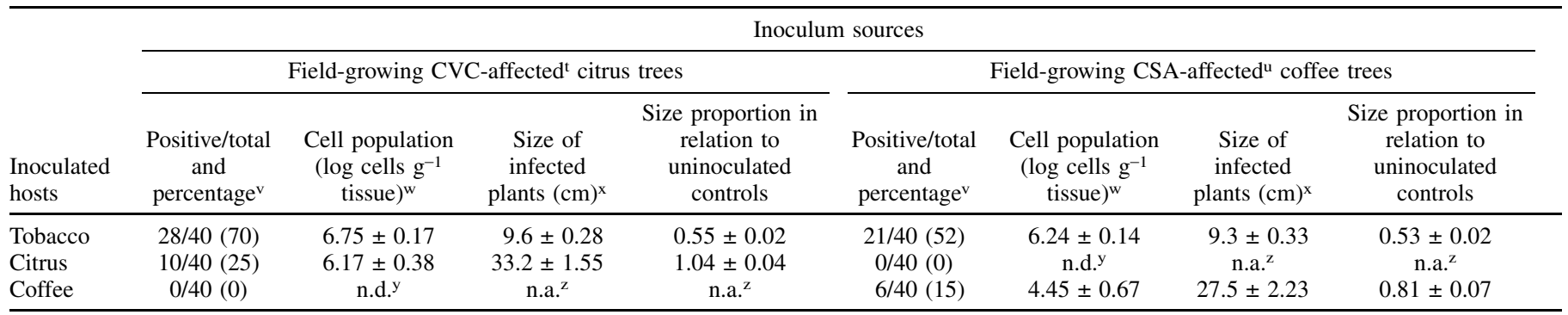

${ }^{t}$ Chlorotic lesions on one side and gummy lesion on the other side of the leaf blade, with some showing necrosis.

u Short internodes and small leaves, with some also showing partial necrosis.

$\checkmark$ The number that is quantitative PCR positive (Li et al. 2013) and in parentheses, the percentage of the inoculated plants that became infected by X. fastidiosa.

${ }^{\mathrm{w}}$ Averages and standard errors.

${ }^{x}$ Height of quantitative PCR-positive plants.

${ }^{y}$ n.d., nondetected amplicons or quantitative PCR quantification cycle values above 34.0.

${ }^{\mathrm{z}}$ n.a., not available. 
from Buritizal (Fig. 1) were used in 2019 to provide more detailed descriptions of tobacco symptoms.

In 2002, the inoculations were carried out at the University of Ribeirão Preto (UNAERP), and in 2014 and 2019, they were carried out at Fundecitrus, both inside greenhouses adapted with a cooling pad fan to prevent the temperature from exceeding $32^{\circ} \mathrm{C}$. The inoculated seedlings were grown individually in cells of foam trays or 1.2-liter pots containing sandy soil plus cow manure (Garcia et al. 2012) or the commercial Plantmax citrus (Eucatex). The seedlings grown in the nutritionally poorer commercial substrate were further irrigated once a week with a solution containing, in 1 liter, $1.35 \mathrm{~g}$ of $\mathrm{Ca}\left(\mathrm{NO}_{3}\right)_{2}, 0.111 \mathrm{~g}$ of monoammonium phosphate, $0.4 \mathrm{~g}$ of $\mathrm{MgSO}_{4}$, $0.015 \mathrm{~g}$ of $\mathrm{Cu}, 0.01 \mathrm{~g}$ of $\mathrm{Zn}, 0.0075 \mathrm{~g}$ of Mn-EDTA, $0.00045 \mathrm{~g}$ of $\left(\mathrm{NH}_{4}\right)_{2} \mathrm{MoO}_{4}$, and $0.075 \mathrm{~g}$ of Fe-EDTA. The fertilized tobacco grew faster and reached larger sizes than those previously grown in soil, and 1 month after inoculation ( 3 months of age), they were pruned at the stem around $5 \mathrm{~cm}$ above the substrate level.

Field surveys. Field surveys were conducted from April to June and in August 2002; in February, April, and August 2014; in May 2018; and in January 2019 in several locations in SPS and one location in Minas Gerais State (Fig. 1). They included highly infected commercial plantings or backyard trees of sweet orange (cultivars Lima, Pera Rio, or Valencia) or coffee (cultivars Catuaí Amarelo, Catuaí Vemelho, Mundo Novo, Robusta, and Sumatra) varieties; in some instances, they were growing side by side with poor or no CVC or CSA disease control measures. The citrus trees expressed typical CVC symptoms (Rossetti et al. 1990), namely chlorotic lesions on the upper side and gummy lesions on the lower side of the leaf blade; some had necrosis. The coffee trees contained branches with short internodes and small leaves (Paradela Filho et al. 1997), with some leaves also showing partial necrosis. Samples consisted of 40- to 50-cm-long symptomatic branches, which were transferred to the laboratory in plastic bags, where the leaves were detached and processed for pathogen isolation. In the 2014 to 2018 surveys, a total of six leaves was separated from each sample, and they were used for DNA extraction (do Carmo Teixeira et al. 2005) and PCR analysis (Li et al. 2013; Pooler and Hartung 1995).

To increase the chances of recovering $X$. fastidiosa in pure cultures, the samples were processed in three different laboratories located at UNAERP in Ribeirão Preto: Instituto Biológico (IB) in Campinas, Universidade de São Paulo (USP) in Piracicaba, and Fundecitrus in Araraquara. Midribs and petioles of symptomatic leaves were washed thoroughly with soap and tap water, surface disinfested in $70 \%$ ethanol for $1 \mathrm{~min}$ and $1 \%$ sodium bleach for $1 \mathrm{~min}$, and dipped twice in two flasks of sterile water. The surfacedisinfested samples were cut in small segments. At UNAERP and IB, they were handle macerated in $1 \mathrm{ml}$ of sterile PBS, and at USP, they were mechanically triturated in $1.8 \mathrm{ml}$ of PBS. The macerated/ triturated tissues were 10- and 100-fold diluted in the same buffer, and four aliquots of $20 \mu \mathrm{l}$ of each dilution were dropped onto the surface of PW agar medium (Davis et al. 1981) near the edge of the plate. The plates were then inclined for the drops to run close to the opposite edge of the plate and incubated for 20 to 30 days at $28^{\circ} \mathrm{C}$. The small and slow-growing colonies typical of $X$. fastidiosa that appeared on the agar surface were transferred individually to $2.0-\mathrm{ml}$ tubes containing $0.5 \mathrm{ml}$ of a modified liquid PW medium (Hill and Purcell 1997), further cultured for an additional 10 days at $28^{\circ} \mathrm{C}$, and then, used to inoculate tobacco. Just before inoculation, the tubes were centrifuged for $3 \mathrm{~min}$ at 20,800 relative centrifugal force, and the pellets were resuspended in $20 \mu \mathrm{l}$ of fresh PW medium. The resuspended pellets were used to pin prick the stems of Nicotiana clevelandii A. Gray or Nicotiana tabacum L. 'RP1' seedlings.

Plant evaluations. Inoculated and noninoculated seedlings were assessed regularly for the presence of symptom on leaves as well as for pathogen detection and quantification by plate dilution isolation in buffered charcoal yeast extract (BCYE) (Wells et al. 1981) or on PW agar medium or through real-time quantitative
PCR (qPCR) as described (Li et al. 2013). Isolations were carried out from midribs and petioles of three leaves per plant (Lopes et al. 2000) at 4 months postinoculation for the tobacco and 6 months postinoculation for the citrus and coffee seedlings. The plates were incubated for 4 weeks when colonies were counted, and the number of CFU per gram of leaf tissue was estimated. For qPCR, DNA was extracted from leaves with the cetyl trimethylammonium bromide method (Murray and Thompson 1980) as described by do Carmo Teixeira et al. (2005) from $0.5 \mathrm{~g}$ of finely chopped midribs and petioles. The DNA samples were quantified and adjusted to $100 \mathrm{ng} / \mu \mathrm{l}$ using the Nanodrop ND-1000 spectrophotometer. qPCR reactions contained $6 \mu \mathrm{l}$ of master mix (Invitrogen), $1 \mu \mathrm{l}$ of DNA sample, and $150 \mathrm{nM}$ primers and marker XF16Sfpr (Li et al. 2013). qPCR was run in a StepOne Plus thermocycler (Applied Biosystems) with the cycling conditions as indicated ( $\mathrm{Li}$ et al. 2013). The XF16Sfpr primers did not differentiate $X$. fastidiosa strains, but they were useful for pathogen quantification in plant tissues ( $\mathrm{Li}$ et al. 2013). Cycle threshold (Ct) values were those automatically adjusted by the StepOne software, with 34.0 as the limit to determine the presence or absence of $X$. fastidiosa amplicons in the extracted DNA. Using the master quantification curve developed by Li et al. (2013), the Ct values were converted in logarithm $\left(\log _{10}\right)$ of amplicon copies and then, used to estimate bacterium titers (number of cells per gram of tissue). In the second trial in 2014, at the time of samplings for qPCR analyses, plant heights also were measured. The impact was determined for each host and group of isolates based on the average proportion of the sizes of all qPCR-positive seedlings in relation to the size of the uninoculated controls.

Statistical analyses. Statistical analyses were applied only to the CFU data of the pathogenicity tests conducted in 2014. The data were normalized through Box-Cox transformation (Osborne 2010) and submitted to analysis of variance. For comparing hosts for each strain, the means were analyzed through Tukey, and for comparing $X$. fastidiosa strains, the pooled means for each host were analyzed through Student's $t$ test. For all analyses, only $X$. fastidiosa-positive samples were considered. The R statistical software (R Core Team

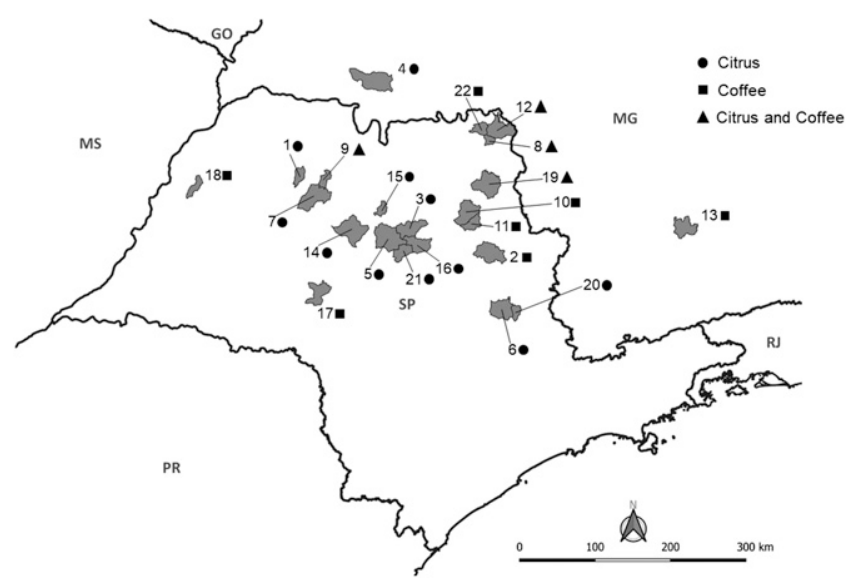

Fig. 1. Geographic distribution of the municipalities and locations where trees of citrus, coffee, or citrus plus coffee (represented by dark circles, squares, or triangles, respectively) were sampled for the presence of Xylella fastidiosa in Brazil. Location and sampled year are as follows: 1 (1992); 2 to 4, 6, 7, 9, 11, and 13 to 18 (2002); 19 and 20 (2014); 8 (2002 and 2014); 5 and 10 (2002 and 2018); and 12 (2002, 2014, and 2018). Locations 1 and 2 are places where the strain $9 \mathrm{a} 5 \mathrm{c}$ of the citrus variegated chlorosis disease and the strain $\mathrm{CaSC}$ of coffee stem atrophy were originally isolated. GO, Goiás; MG, Minas Gerais; MS, Mato Grosso do Sul; PR, Paraná; SP, São Paulo; RJ, Rio de Janeiro; 1, Macaubal; 2, Santa Rita do Passa Quatro; 3, Taquaritinga; 4, Comendador Gomes; 5, Itápolis; 6, Araras; 7, Jose Bonifácio; 8, Jeriquara; 9, Neves Paulista; 10, Ribeirão Preto; 11, Cravinhos; 12, Pedregulho (Alto Porã district); 13. Lavras; 14, Novo Horizonte; 15. Pindorama; 16, Matão; 17, Garça; 18, Muritinga do Sul; 19, Batatais; 20, Conchal; 21, Tabatinga; and 22, Butitizal. 
2014) was used for all analyses, and the significance levels of $P<0.05$ discriminated the means.

\section{RESULTS}

The suitability of tobacco to distinguish the CVC and CSA pathogens, first observed in 2001 (Lopes 2001), was confirmed and extended in this work using different types of tobacco and several isolates from infected citrus and coffee trees from different locations and sampling dates (Fig. 1). The distinct symptoms are illustrated in Figure 2A and B for 2002, and they are illustrated in Figure 2C to K for 2019.

Most symptomatic tobacco plants showed shorter internodes and reached average heights nearly one-half those of the uninoculated controls (Fig. 2A, second to fifth rows, and Table 2). On leaves, the CVC pathogen induced dark orange lesions first observed 6 to

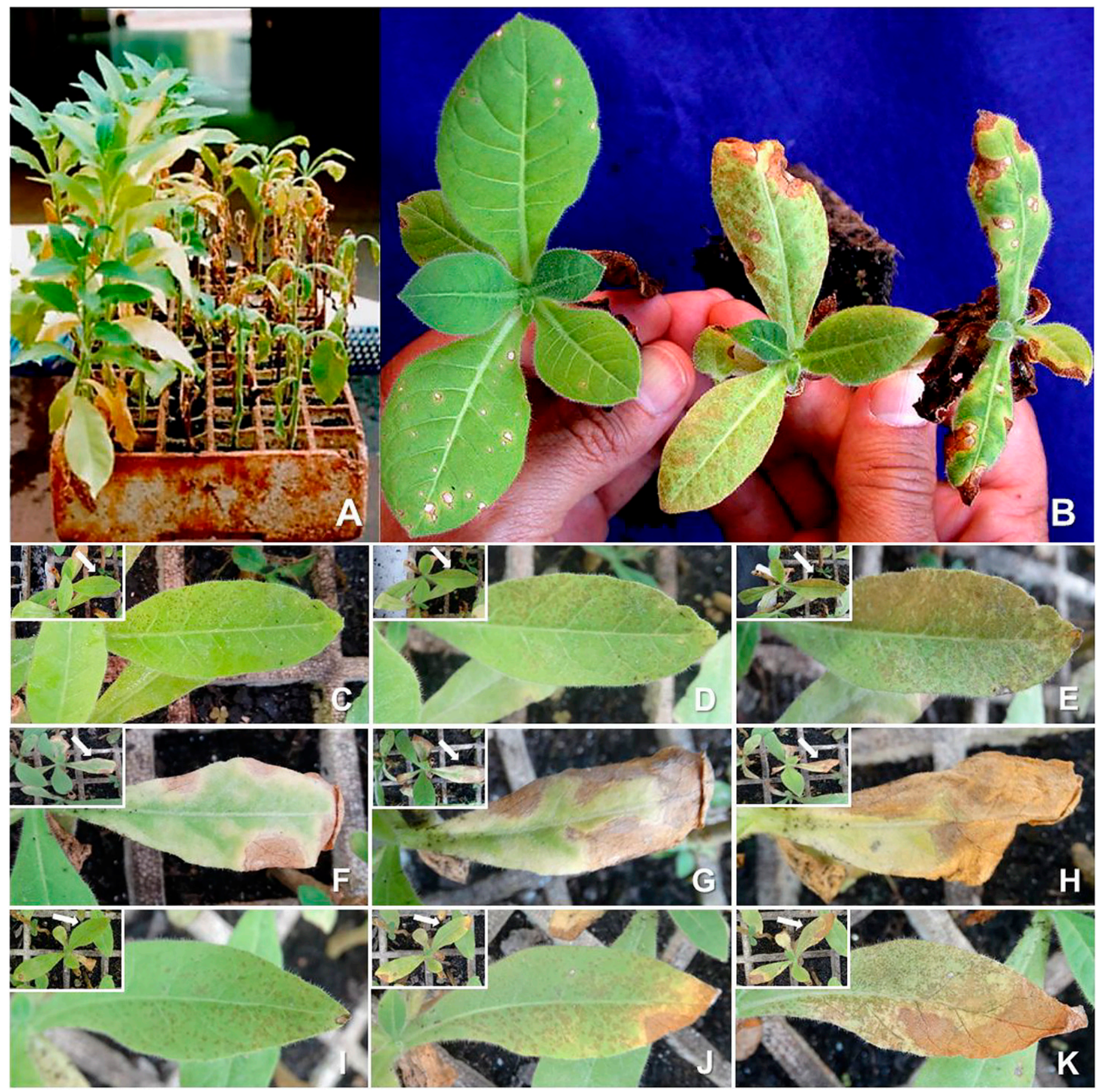

Fig. 2. Aspects of Nicotiana tabacum 'RP1' seedlings inoculated with distinct strains or isolates of Xylella fastidiosa recovered from sweet orange and coffee trees from several locations of Brazil (Fig. 1). A, The first row in the foam tray includes seedlings pin pricked with phosphate-buffered saline alone (uninoculated control), and the second to fifth rows are seedlings inoculated with the strain 9a5c of citrus variegated chlorosis (CVC) disease. B, The left image is an uninoculated seedling, and the center and right images are seedlings inoculated with strain 9a5c of CVC and strain CaSC of coffee stem atrophy (CSA) disease, respectively. $\mathbf{C}$ to E, A seedling inoculated with a CVC isolate from Tabatinga. $\mathbf{F}$ to $\mathbf{H}$, A seedling inoculated with a CSA isolate from Buritizal. I to K, A seedling inoculated with a mix of CVC and CSA isolates from Tabatinga and Buritizal. A and B, Pictures were taken 4 months after the 2002 inoculation. $\mathbf{C}$ to E, Pictures were taken from the same seedling at 78 to 93 days after the 2019 inoculation. F to H, Pictures were taken from the same seedling at 83 to 89 days after the 2019 inoculation. I to K, Pictures were taken from the same seedling at 84 to 93 days after the 2019 inoculation. $\mathbf{C}$ to $\mathbf{K}$, Insets show the image of the whole seedling, with the white arrows indicating the leaf shown in the larger panels. 
8 weeks postinoculation (Fig. $2 \mathrm{~B}$, center image, and C to E). New lesions continued to appear on the entire blade of old and young leaves and gradually progressed to leaf necrosis, which in most cases, remained limited to the leaf blade (Fig. 2E). Symptom appearance, aspects, and progress were similar for all types of tobacco, regardless of the CVC strain/isolate used as inoculum (Tables 1 to 3 ). In contrast, the CSA pathogen induced an irregular chlorosis at the edges of the older leaves that was first observed 10 to 12 weeks after inoculation (Fig. 2B, right image, and $\mathrm{F}$ to $\mathrm{H}$ ). After 1 to 2 weeks from the initial symptom detection, the chlorosis had progressed to necrosis and leaf atrophy, affecting the blade and main vein (Fig. $2 \mathrm{H}$ ). As with the CVC pathogen, symptom appearance, aspects, and progress were similar for all types of tobacco regardless of the CSA strain/isolate used as inoculum. In 2019, a set of 18 tobacco seedlings was also inoculated with a cell suspension mixture of isolates recovered from citrus and coffee. In this group of seedlings, a combination of symptom patterns induced by both pathogens (Fig. 2I to K) was observed in 12 of the 18 inoculated seedlings, with no apparent influence of one pathogen on the other. As a consequence of the weekly fertilization, the tobacco seedlings grown in commercial substrate reached approximately $40 \mathrm{~cm}$ 3 months after seeding, and they were pruned around $5 \mathrm{~cm}$ above substrate level. The pruning procedure did not interfere with symptom appearance and development.

In 2002 and 2014, citrus and coffee seedlings also were inoculated with the same cell suspensions used for tobacco inoculations (Tables 1 and 2). Only citrus seedlings inoculated with the CVC strain/isolate and coffee seedlings inoculated with the CSA strain/ isolate became infected. Leaf symptoms similar to those found in the field or in artificially inoculated seedlings (Garcia et al. 2012) were observed on citrus 6 months postinoculation. There were no differences in size among inoculated and control plants. Although no symptom developed on inoculated coffee plants, infected plants were on average approximately $20 \%$ smaller than the uninoculated controls.

In 2002, leaf samples were processed for pathogen isolation on BCYE medium 4 to 6 months postinoculation. $X$. fastidiosa colonies were recovered from most symptomatic tobacco, all symptomatic citrus inoculated with the CVC strain, and four asymptomatic coffee seedlings inoculated with the CSA strain (Table 1). Overall, the pathogen was isolated at higher frequencies and at significantly higher titers $(t=2.259 ; P=0.0268)$ from seedlings inoculated with the CVC $(64.4 \%$; average $7.53 \pm 0.14$ $\log _{10}$ CFU per gram of tissue) than from seedlings inoculated with the CSA strain (42.5\%; average $6.93 \pm 0.24 \log _{10}$ CFU per gram of tissue) (Table 1). Differences were also found among hosts within each strain $\left(F_{6,39}=8.24\right.$ and $P<0.0001$ for the CVC; $F_{6,24}=4.80$ and $P<0.0024$ for the CSA strain). The $\mathrm{CVC}$ strain reached higher titers in $N$. tabacum 'RP1' $(8.29 \pm 0.11)$ and lower titers in the cultivar Burley $(6.99 \pm 0.34)$ and citrus $(6.37 \pm 0.56)$. The CVC strain did not colonize coffee. The CSA strain attained higher titers in tobacco $(7.17 \pm 0.09$ to $7.70 \pm 0.42)$ and lower titers in coffee $(3.93 \pm 0.57)$. The CSA strain did not colonize citrus.

In 2014, DNA was extracted from leaf samples for qPCR analyses from all tobacco, citrus, and coffee seedlings inoculated individually with $80 \mathrm{X}$. fastidiosa isolates recovered from tobacco (40 from tobacco inoculated with the CVC isolate and 40 from tobacco inoculated with CSA isolate). qPCR revealed the presence of the bacterium in 70 and $25 \%$ of the tobacco and citrus seedlings, respectively, inoculated with the CVC isolates, with average titers of $6.75 \pm 0.17$ and $6.17 \pm 0.38$ cells per gram of tissue, respectively. qPCR also revealed the presence of the bacterium in 52 and $15 \%$ of the tobacco and coffee seedlings, respectively, inoculated with the CSA isolates, with average titers of $6.24 \pm 0.14$ and $4.45 \pm 0.67$ cells per gram of tissue, respectively. X. fastidiosa was not detected in any of the coffee seedlings inoculated with the CVC isolates or citrus seedlings inoculated with the CSA isolates. Additionally, $X$. fastidiosa was not detected in any of the 20 seedlings of each host used as uninoculated controls.

The ability to discriminate the CVC from CSA strain of $X$. fastidiosa was used in a study to assess the eventual occurrence mixed infections in the same coffee or citrus trees growing in the field, in neighboring or isolated crops, distributed in several regions, in three time periods 12 to 16 years apart (Fig. 1 and Supplementary Table S1). In four locations, the same crops sampled in 2002 were resampled in 2014. Because of the presence of fast-growing contaminants, mainly bacteria, we failed to recover the pathogen in several attempts. Failures were more frequent during February and April 2014 and less frequent in June and August 2002 and August 2014 for both groups of isolates. Successfully recovered $X$. fastidiosa colonies were individually inoculated onto $N$. clevelandii or N. tabacum 'RP1' seedlings (one colony per seedling) after additional growth in liquid medium.

Overall, of the 911 colonies recovered from citrus, 54 to $88 \%$ of them induced symptoms in tobacco in the assays conducted in June 2002 and May 2018. In all cases, symptom appearance and progression in time (Fig. $2 \mathrm{C}$ to $\mathrm{E}$ ) were similar to that induced by the CVC pathogen used in previous inoculation experiments, with overall $25.5 \%$ of the inoculated tobacco not expressing any symptom. Similarly, of the 381 colonies recovered from coffee in the three time periods in which the pathogen was recovered in culture medium, $65.9 \%$ of them induced symptoms in tobacco, with the percentage varying from 52\% in August 2018 to 64 and 74\% in August and June 2002, respectively. In all cases, symptom appearance and progression in time (Fig. $2 \mathrm{~F}$ to $\mathrm{H}$ ) were similar to

TABLE 3. Responses of cultivar RP1 of Nicotiana tabacum to inoculations of individual colonies of Xylella fastidiosa recovered from trees of citrus or coffee growing in several locations of Brazil in three time periods

\begin{tabular}{|c|c|c|c|c|c|}
\hline \multirow[b]{2}{*}{ Host and date } & \multirow[b]{2}{*}{ Surveyed locations ${ }^{\mathrm{w}}$} & \multirow[b]{2}{*}{ Total inoculated colonies ${ }^{\mathrm{x}}$} & \multicolumn{3}{|c|}{ Symptoms in tobacco (percentage) } \\
\hline & & & Dark orange lesions ${ }^{\mathrm{y}}$ & Chlorotic/necrotic lesions ${ }^{\mathrm{Z}}$ & No symptoms \\
\hline \multicolumn{6}{|l|}{ Citrus } \\
\hline April 2002 & 3 & 180 & $109(61)$ & 0 & $71(39)$ \\
\hline June 2002 & 8,9 & 225 & $198(88)$ & 0 & $27(12)$ \\
\hline August 2002 & $14,15,16$ & 223 & $183(82)$ & 0 & $40(18)$ \\
\hline August 2014 & $8,12,20$ & 149 & $82(55)$ & 0 & $67(45)$ \\
\hline August 2002 & 17,18 & 90 & 0 & $58(64)$ & $32(36)$ \\
\hline August 2014 & 12 & 102 & 0 & $53(52)$ & $49(48)$ \\
\hline
\end{tabular}


those induced by the CSA pathogen used in previous inoculation experiments, with overall $34.1 \%$ of the inoculated tobacco not expressing any visible symptom.

\section{DISCUSSION}

In this work, we confirmed that tobacco is highly susceptible to the CVC or CSA pathogens, and it responds to infection by expressing distinct leaf symptoms. The responses were similar for several varieties of $N$. tabacum and the species $N$. clevelandii. The CSA pathogen required 3 to 4 weeks longer than the CVC pathogen to induce symptoms in tobacco, but after they started, they progressed faster, culminating in death of several seedlings. The high susceptibility of tobacco to $X$. fastidiosa infection (shown in this work for the strains/isolates that affect citrus and coffee and shown in other works for the strains that affect almond, grape, blueberry, and pecan [Amanifar et al. 2014; De La Fuente et al. 2013; Francis et al. 2008; Qin and Hartung 2004]) indicates that, in the presence of an efficient insect vector, this pathogen could lead to severe detrimental impacts on tobacco production, such as has occurred with olive trees in Europe (Saponari et al. 2013).

The symptoms induced by $X$. fastidiosa in tobacco were strain specific. On seedlings inoculated with the CVC pathogen, the symptoms never started with irregular chlorosis. Similarly, on seedlings inoculated with the CSA pathogen, the symptoms never started or progressed to dark orange lesions. To a certain extent, these symptoms are analogous to citrus and coffee responses to $X$. fastidiosa. In citrus, the initial lesions are not necrotic, contrary to what happens in coffee: in addition to short internodes and small leaves (Paradela Filho et al. 1997), the infected trees also may exhibit leaf scald (de Lima et al. 1998).

The differential responses of tobacco also indicate that, although genetically very similar and belonging to the same subspecies (Nunney et al. 2014), the CVC and CSA pathogens must have distinct mechanisms of pathogenicity. Because both pathogens were isolated at least $10 \mathrm{~cm}$ distant from the inoculum site and were at similar concentrations, the differences in pathogenicity must be associated with the final process of plant colonization when specific pathogenicity genes leading to the induction of distinct leaf symptoms are activated. It would be interesting to investigate in the pathogen and in the host the genes that are involved in these responses. Xylem plugging and the consequent obstruction of sap flow are not the only mechanisms by which $X$. fastidiosa causes disease (Baccari and Lindow 2011).

The differential responses of tobacco to $X$. fastidiosa infection, observed initially for the strains $9 \mathrm{a} 5 \mathrm{c}$ and CaSC, were later confirmed with isolates recovered from infected citrus and coffee trees from several geographic locations. The lack of an easy protocol to separate both pathogens (Almeida et al. 2008) and the difficulties in reproducing CSA symptoms under experimental conditions, which were observed previously (Prado et al. 2008) and confirmed in this work, indicate that tobacco would be a useful tool for epidemiological studies. The possibility of growing tobacco in foam trays, such as has already been shown for citrus (Lopes et al. 2005), allows for testing large numbers of isolates in limited spaces. Strong fertilization did not interfere with the systemic infection process but stimulated seedling development. Pruning the fast-growing plants facilitated symptom observation on the new developed shoots.

The suitability of tobacco inoculations to discriminate the strain of $X$. fastidiosa affecting citrus from that affecting coffee was here confirmed in an additional work carried out with the objective to determine whether these strains would be moving between citrus and coffee crops through insect vectors, which are very common in both crops and able to transmit both pathogens (Marucci et al. 2008). Bacterial establishment in citrus and coffee trees would result in mixed infections that, using isolated colonies recovered from field-grown diseased trees as inoculum, would be identified by tobacco inoculations. The results of surveys carried out in several locations in four time intervals 12 to 16 years apart indicated, however, that cross-infections are not happening, confirming results of a study from 2017 that used molecular protocols (Francisco et al. 2017). As a practical outcome, this result may eliminate grower concerns of one crop serving as the source of inoculum for the other crop.

In the field, the limitation of CVC and CSA pathogens to their original hosts may be related to their inability to infect citrus and coffee. This is contrary to previous observations (Li et al. 2001; Prado et al. 2008). In the work by Li et al. (2001), the CVC pathogen caused disease in coffee. In the work by Prado et al. (2008), the CVC pathogen infected coffee; however, in this case, the infection succeeded only when the coffee plants were artificially inoculated with a much higher inoculum concentration. Therefore, the relative nonspecificity of the CVC pathogen observed before may have resulted from the use of an inoculation condition that was too artificial.

Nearly one-fourth and one-third of the X. fastidiosa colonies recovered from citrus and coffee trees, respectively, were nonpathogenic. The reason for these mixed populations in plant tissues is unknown, but it explains the existence of strains like the J1a12 isolated from citrus (Monteiro et al. 2001), which induced few or no CVC symptoms in citrus and tobacco plants and varied in the number of coding sequences compared with the pathogenic strain $9 \mathrm{a} 5 \mathrm{c}$ (Koide et al. 2004). The occurrence of high proportions of nonpathogenic isolates of $X$. fastidiosa in citrus and coffee trees may indicate that this phenomenon is more common than we suspected.

In this work, we observed that the difficulties in recovering $X$. fastidiosa in pure cultures from field-grown trees varies throughout the year, becoming more challenging during February and April when the plates remained clean in many instances. In others, fast-growing bacteria invaded the plates in 3 to 4 days, impeding growth and/or not allowing visualization of any colony of the slow-growing $X$. fastidiosa eventually present. The difficulties with contaminants prevailed despite the efforts to avoid them by carrying out serial dilutions of the macerate before plating. The unknown contaminant bacteria could be composed of organisms not eliminated during the sample preparation or bacteria sharing the same niche as $X$. fastidiosa (the xylem), with some species already demonstrated to impact pathogen multiplication (Lacava et al. 2004). The members of this endophyte community also seem to be impacted by the environment. The frequency of their occurrence was higher during the hotter and wetter months, periods when the trees grow more actively, and this probably resulted in changes in xylem sap flow dynamics and composition.

\section{ACKNOWLEDGMENTS}

We thank L. W. Timmer, retired Professor Emeritus, University of Florida, Lake Alfred, and A. G. Beattie, retired professor of the University of Southern Sydney, for useful suggestions during manuscript preparation.

\section{LITERATURE CITED}

Almeida, R. P. P., Nascimento, F. E., Chau, J., Prado, S. S., Tsai, C. W., Lopes, S. A., and Lopes, J. R. S. 2008. Genetic structure and biology of Xylella fastidiosa causing disease in citrus and coffee in Brazil. Appl. Environ. Microbiol. 74:3690-3701.

Alves, E., Kitajima, E. W., and Leite, B. 2003. Interaction of Xylella fastidiosa with different cultivars of Nicotiana tabacum: A comparison of colonization patterns. J. Phytopathol. 151:500-506.

Amanifar, N., Taghavi, M., Izadpanah, K., and Babaei, G. 2014. Isolation and pathogenicity of Xylella fastidiosa from grapevine and almond in Iran. Phytopathol. Mediterr. 53:318-327.

Ayres, A. J. 2000. Intensidade da clorose variegada dos citros em pomares comerciais de laranja do estado de São Paulo e sul do triângulo mineiro. MSc dissertation. Universidade Estadual Paulista, Jaboticabal, Brasil.

Baccari, C., and Lindow, S. E. 2011. Assessment of the process of movement of Xylella fastidiosa within susceptible and resistant grape varieties. Phytopathology 101:77-84. 
Bové, J. M., and Ayres, A. J. 2007. Etiology of three recent diseases of citrus in São Paulo State: Sudden death, variegated chlorosis and huanglongbing. IUBMB Life 59:346-354.

Chang, C. J., Garnier, M., Zreik, L., Rossetti, V., and Bové, J. M. 1993. Citrus variegated chlorosis: Cultivation of the causal bacterium and experimental reproduction of the disease. Pages 294-300 in: Proc. 12th Conf. Int. Org. Citrus Virol., Riverside, CA.

Coletta-Filho, H. D., Francisco, C. S., Lopes, J. R. S., Oliveira, A. F., and Silva, L. F. O. 2016. First report of olive leaf scorch in Brazil associated with Xylella fastidiosa subsp. pauca. Phytopathol. Mediterr. 55:130-135.

Davis, M. J., French, W. J., and Schaad, N. W. 1981. Axenic culture of the bacteria associated with phony disease of peach and plum leaf scald. Curr. Microbiol. 6:309-314.

De La Fuente, L., Parker, J. K., Oliver, J. E., Granger, S., Brannen, P. M., Santen, E. V., and Cobine, P. A. 2013. The bacterial pathogen Xylella fastidiosa affects the leaf ionome of plant hosts during infection. PLoS One 8:e62945.

de Lima, J. E. O., Miranda, V. S., Hartung, J. S., Brlansky, R. H., Coutinho, A., Roberto, S. R., and Carlos, E. F. 1998. Coffee leaf scorch bacterium: Axenic culture, pathogenicity, and comparison with Xylella fastidiosa of citrus. Plant Dis. 82:94-97.

do Carmo Teixeira, D., Danet, J. L., Eveillard, S., Martins, E. C., Jesus, Jr., W. C., Yamamoto, P. T., and Bové, J. M. 2005. Citrus huanglongbing in São Paulo State, Brazil: PCR detection of the 'Candidatus' Liberibacter species associated with the disease. Mol. Cell. Probes 19:173-179.

Francis, M., Civerolo, E. L., and Bruening, G. 2008. Improved bioassay of Xylella fastidiosa strains using Nicotiana tabacum cultivar SR1. Plant Dis. 92:14-20.

Francisco, C. S., Ceresini, P. C., Almeida, R. P. P., and Coletta-Filho, H. D. 2017. Spatial genetic structure of coffee-associated Xylella fastidiosa populations indicates that cross infection does not occur with sympatric citrus orchards. Phytopathology 107:395-402.

Fundecitrus. 2018. Levantamento de doenças dos citros: Resultados do greening, CVC e cancro cítrico 2018. Araraquara, SP, Brazil. https:// www.fundecitrus.com.br/pdf/palestras/ResultadosZ-ZlevantamentoZanualZdaZincidnciaZdasZdoenas.pdf

Garcia, A. L., Torres, S. C. Z., Heredia, M., and Lopes, S. A. 2012. Citrus responses to Xylella fastidiosa infection. Plant Dis. 96:1245-1249.

Garnier, M., Chang, C. J., Zreik, L., Rossetti, V., and Bové, J. M. 1993. Citrus variegated chlorosis: Serological detection of Xylella fastidiosa, the bacterium associated with the disease. Pages 301-305 in: Proc. 12th Conf. Int. Org. Citrus Virol., Riverside, CA.

Hill, B. L., and Purcell, A. H. 1997. Populations of Xylella fastidiosa in plants required for transmission by an efficient vector. Phytopathology 87: 1197-1201.

Koide, T., Zaini, P. A., Moreira, L. M., Vêncio, R. Z., Matsukuma, A. Y., Durham, A. M., Teixeira, D. C., El-Dorry, H., Monteiro, P. B., Silva, A. C., Verjovski-Almeida, S., Silva, A. M., and Gomes, S. L. 2004. DNA Microarray-based genome comparison of a pathogenic and a nonpathogenic strain of Xylella fastidiosa delineates genes important for bacterial virulence. J. Bacteriol. 186:5442-5449.

Lacava, P. T., Araújo, W. L., Marcon, J., Maccheroni, Jr., W., and Azevedo, J. L. 2004. Interaction between endophytic bacteria from citrus plants and the phytopathogenic bacterium Xylella fastidiosa, causal agent of citrus variegated chlorosis. Lett. Appl. Microbiol. 39:55-59.

Li, W., Pria, Jr., W. D., Teixeira, D. C., Miranda, V. S., Ayres, A. J., Franco, C. F., and Costa, M. G. 2001. Coffee leaf scorch caused by a strain of Xylella fastidosa from citrus. Plant Dis. 85:501-505.

Li, W. B., Teixeira, D. C., Hartung, J. S., Huang, Q., Duan, Y. P., Zhou, L. J., Chen, J., Lin, H., Lopes, S., Ayres, A. J., and Levy, L. 2013. Development and systematic validation of qPCR assays for rapid and reliable differentiation of Xylella fastidiosa strains causing citrus variegated chlorosis. J. Microbiol. Methods 92:79-89.

Lopes, S. A. 2001. Reação diferencial de variedades de fumo à Xylella fastidiosa de citros e café. Fitopatol. Bras. 26:305.

Lopes, S. A., Laranjeira, F. F., Amorim, L., and Bergamin Filho, A. 2004. Clorose variegada: Perdas anuais de US\$ 100 milhões. Visao Agric. 1:20-23.

Lopes, S. A., Ribeiro, D. M., Roberto, P. G., França, S. C., and Santos, J. M. 2000. Nicotiana tabacum as an experimental host for the study of plantXylella fastidiosa interactions. Plant Dis. 84:827-830.

Lopes, S. A., Teixeira, D. C., Fernandes, N. G., and Ayres, A. J. 2005. An experimental inoculation system to study citrus-Xylella fastidiosa interactions. Plant Dis. 89:250-254.

Marucci, R. C., Lopes, J. R. S., and Cavachioli, R. R. 2008. Transmission efficiency of Xylella fastidiosa by sharpshooters (Hemiptera: Cicadellidae) in coffee and citrus. J. Econ. Entomol. 101:1114-1121.
Monteiro, P. B., Teixeira, D. C., Palma, R. R., Garnier, M., Bové, J. M., and Renaudin, J. 2001. Stable transformation of the Xylella fastidiosa citrus variegated chlorosis strain with oriC plasmids. Appl. Environ. Microbiol. 67:2263-2269

Murray, M. G., and Thompson, W. F. 1980. Rapid isolation of high molecular weight plant DNA. Nucleic Acids Res. 8:4321-4326.

Nunney, L., Ortiz, B., Russell, S. A., Ruiz Sánchez, R., and Stouthamer, R. 2014. The complex biogeography of the plant pathogen Xylella fastidiosa: Genetic evidence of introductions and subspecific introgression in Central America. PLoS One 9:e112463.

Osborne, J. W. 2010. Improving your data transformations: Applying the BoxCox transformation. Pract. Assess., Res. Eval. 15:1-9.

Paradela Filho, O., Sugimori, M. H., Ribeiro, I. J. A., Garcia Jr. A., Beretta, M. J. G., Harakava, R., Machado, M. A., Laranjeira, F. F., Rodrigues Neto, J., and Beriam, L. O. S. 1997. Constatação de Xylella fastidiosa em cafeeiro no Brasil. Summa Phytopathol. 23:46-49.

Pooler, M. R., and Hartung, J. S. 1995. Specific PCR detection and identification of Xylella fastidiosa strains causing citrus variegated chlorosis. Curr. Microbiol. 31:377-381.

Prado, S., Lopes, J. R. S., Demetrio, C., Borgatto, A., and Almeida, R. P. P. 2008. Host colonization differences between citrus and coffee isolates of Xylella fastidiosa in reciprocal inoculation. Sci. Agric. 65:251-258.

Qin, X., and Hartung, J. S. 2004. Expression of green fluorescent protein in Xylella fastidiosa is affected by passage through host plants. Curr. Microbiol. 49:215-220.

R Core Team. 2014. R: A Language and Environment for Statistical Computing. http://www.r-project.org

Rossetti, V., Garnier, M., Bové, J. M., Beretta, M. J. G., Teixeira, A. R. R., Quaggio, J. A., and De Negri, J. D. 1990. Présence de bactéries dans le xylème d'orangers atteints de chlorose variégé, une nouvelle maladie des agrumes au Bresil. C. R. Acad. Sci. 30:345-349.

Saponari, M., Boscia, D., Nigro, F., and Martelli, G. P. 2013. Identification of DNA sequences related to Xylella fastidiosa in oleander, almond and olive trees exhibiting leaf scorch symptoms in Apulia (southern Italy). J. Plant Pathol. 95:668.

Schaad, N. W., Postnikova, E., Lacy, G., Fatmi, M., and Chang, C. J. 2004. Xylella fastidiosa subspecies: X. fastidiosa subsp. piercei, subsp. nov., $X$. fastidiosa subsp. multiplex subsp. nov., and X. fastidiosa subsp. pauca subsp. nov. Syst. Appl. Microbiol. 27:290-300.

Simpson, A. J. G., Reinach, F. C., Arruda, P., Abreu, F. A., Acencio, M., Alvarenga, R., Alves, L. M. C., Araya, J. E., Baia, G. S., Baptista, C. S., Barros, M. H., Bonaccorsi, E. D., Bordin, S., Bové, J. M., Briones, M. R. P., Bueno, M. R. P., Camargo, A. A., Camargo, L. E. A., Carraro, D. M., Carrer, H., Colauto, N. B., Colombo, C., Costa, F. F., Costa, M. C. R., Costa-Neto, C. M., Coutinho, L. L., Cristofani, M., Dias-Neto, E., Docena, C., El Dorry, H., Facincani, A. P., Ferreira, A. J. S., Ferreira, V. C. A, Ferro, J. A., Fraga, J. S., França, C., Franco, M. C., Frohme, M., Furlan, L. R., Garnier, M., Goldman, G. H., Goldman, M. H. S., Gomes, S. L., Gruber, A., Ho, P. L., Hoheisel, J. D., Junqueira, M. L., Kemper, E. L., Kitajima, J. P., Krieger, J. E., Kuramae, E. E., Laigret, F., Lambais, M. R., Leite, L. C. C., Lemos, E. G. M., Lemos, M. V. F., Lopes, S. A., Lopes, C. R., Machado, J. A., Machado, M. A., Maderia, A. M. B. N., Maderia, H. M. F., Marino, C. L., Marques, M. V., Martins, E. A. L., Martins, E. M. F., Matsukuma, A. Y., Menck, C. F. M., Miracca, E. C., Miyaki, C. Y., Monteiro-Vitorello, C. B., Moon, D. H., Nagai, M. A., Nascimento, A. L. T. O., Netto, L. E. S., Nhani, A., Nobrega, F. G., Nunes, L. R., Oliveira, M. A., Oliveira, M. C., De Oliveira, R. C., Palmieri, D. A., Paris, A., Peixoto, B. R., Pereira, G. A. G., Pereira H. A., Pesquero, J. B., Quaggio, R. B., Roberto, P. G., Rodrigues, V., Rosa, A. J. M., De Rosa V. E., Jr., De Sa, R. G., Santelli, R. V., Sawasaki, H. E., Da Silva, A. C. R., Da Silva, A. M., Da Silva, F. R., Silva, W. A., and Da Silveira, J. F., Silvestri, M. L.Z., Siqueira, W. J., de Souza, A. A., de Souza, A. P., Terenzi, M. F., Truffi, D., Tsai, Tsuhako, S. M.M. H., Vallada, H., Van Sluys, M. A., Verjovski-Almeida, S., Vettore, A. L., Zago, M. A., Zatz, M., Meidanis, J., Setubal, J. C. 2000. The genome sequence of the plant pathogen Xylella fastidiosa: The Xylella fastidiosa consortium of the organization for nucleotide sequencing and analysis, Sao Paulo, Brazil. Nature 406:151-157.

Wells, J. M., Raju, B. C., Hung, H. Y., Weisburg, W. G., Mandelco-Paul, L., and Brenner, D. J. 1987. Xylella fastidiosa gen. nov. sp. nov: Gramnegative, xylem-limited, fastidious plant bacteria related to Xanthomonas spp. Int. J. Syst. Bacteriol. 37:136-143.

Wells, J. M., Raju, B. C., Nyland, G., and Lowe, S. K. 1981. Medium for isolation and growth of bacteria associated with plum leaf scald and phony peach diseases. Appl. Environ. Microbiol. 42:357-363. 